\begin{tabular}{|c|c|c|}
\hline 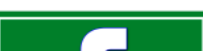 & Int.J.Curr.Microbiol.App.Sci (2021) 10(08): 134-139 & \\
\hline & $\begin{array}{l}\text { International Journal of Current Microbiology and Applied Sciences } \\
\text { ISSN: 2319-7706 Volume } 10 \text { Number } 08 \text { (2021) } \\
\text { Journal homepage: http://www.ijcmas.com }\end{array}$ & 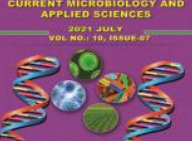 \\
\hline $\begin{array}{l}\text { EXCELLENT } \\
\text { PUBLISHERS }\end{array}$ & & \\
\hline
\end{tabular}

\title{
Studies on Influence of Growth Retardants in Increasing Yield and Yield Attributing Traits in Bellary Onion (Alium cepa var.Cepa)
}

\author{
M. I. Manivannan ${ }^{1 *}$, J. Prem Joshua ${ }^{2}$ and R. Arulmozhiyan ${ }^{3}$ \\ ${ }^{1}$ Department of Horticulture, Horticultural Research Station, \\ Kodaikanal-624 103, Tamil Nadu, India \\ ${ }^{2}$ Department of Post-Harvest Technology, Horticultural College and Research Institute, \\ Periyakulam-625 601, Tamil Nadu, India \\ ${ }^{3}$ Department of Horticulture, Agricultural College \& Research Institute, Killikulam-628252, \\ Tamil Nadu, India \\ *Corresponding author
}

A B S T R A C T

Keywords

Growth retardants, Bellary Onion, Yield, Yield attributing traits

Article Info

\section{Accepted:}

12 July 2021

Available Online:

10 August 2021
A field experiment was conducted at Department of Horticulture, Agricultural College \& Research Institute, Killikulam, Thoothukudi district of Tamil Nadu during Rabi 2018 to study the influence of various growth hormones on bulb size and yield increase and to standardize the appropriate hormone and concentration for increasing the yield and yield attributing traits in onion cv. Agrifound Light Red. The experiment consisted of 9 treatments in various concentrations of four growth retardants, viz. Chlormequat, Mepiquat chloride, Brassinolide and Daminozide. The results revealed that among different growth retardants, Mepiquat chloride $500 \mathrm{ppm}$ significantly reduced the plant height $(55.10 \mathrm{~cm})$, increased the number of leaves per plant (10.10) at 90 days after sowing, neck diameter $(2.25 \mathrm{~cm})$, root length $(8.15 \mathrm{~cm})$ and total chlorophyll content of leaves $(2.49 \mathrm{mg} / \mathrm{g})$. The day taken for maturity was recorded minimum in Mepiquat chloride $500 \mathrm{ppm}(127.30)$ while maximum was recorded in control (135.66). Mepiquat chloride $500 \mathrm{ppm}$ application also significantly improved the yield attributing characters viz., bulb diameter $(5.86 \mathrm{~cm})$, bulb height $(5.28 \mathrm{~cm})$, bulb weight $(76.00 \mathrm{~g})$, marketable yield of bulb/ha(512.15 q) and reduced unmarketable yield of bulb/ha(36.195 q)thereby exerting superiority over other treatments and control for total yield of bulb/ha(548.35 q).

\section{Introduction}

Onion (Allium cepa L.) is one of the most important vegetable bulb crop which is extensively grown in India for local consumption and export. It is widely used both as raw and matured bulb and is also meant to add flavour to various delicious curries. It is usually served cooked, as a vegetable or part of a prepared savoury dish, but can also be 
eaten raw or used to make pickles or chutneys. Onion is also used for various medicinal purposes (Pandey, 2017). Indispensable as vegetables, spice, and condiment, onion commands extensive internal and external markets and consequently the growers receive very good return from this crop. However, there is a need for development of new alternative areas for onion bulb production to meet the market demand of quality bulbs. Despite many attempts in the recent past, to enhance the yield and quality of onion bulbs (Bhonde et al., 1996), no definite and profitable technology has yet been developed which can be recommended to the farmers for growing onion bulb at commercial scale under south Indian conditions where climatic conditions change suddenly during maturity of bulb crop. Growth retardants like Mepiquat chloride, Chlormequat and Daminozide etc., controls plant height and earliness, thus facilitating crop management and harvest. Growth retardants in general and Mepiquat chloride in particular inhibit giberellic acid synthesis consequently reducing cell enlargement and cell division rate(Srivastava, 2002). This would consequently may have effect on bulb size, yield and quality. In onion, suitability of plant growth retardants in terms of quantity and quality of onion bulb isyet to be worked out. With this backdrop, the present investigation was carried out to find out the influence of various growth retardants on bulb size and yield.

\section{Materials and Methods}

A field experiment was carried out during Rabi 2018 at the Department of Horticulture, Agricultural College \& Research Institute, Killikulam, Thoothukudi district. Medium size (60-80 gm) bulbs of onion cv. Agrifound Light Red were used as planting materials in the experiment. The four growth retardants, viz. Chlormequat, Mepiquat chloride, Brassinolide and Daminozide were used in the experiment. These growth retardants were dissolved in water asper the treatment concentration and bulbs were soaked in solution for overnight (Table 1). Treated bulbs were dried in shade and then planted in $3 \mathrm{~m} \times 3 \mathrm{~m}$ plots with $60 \times 30 \mathrm{~cm}$ spacing. The foliar spray of growth retardants were given according to treatment concentration at $35^{\text {th }}$ day after transplanting. All the recommended package of practices was uniformly followed in all treatments. The observations on growth and yield attributes were recorded from randomly selected 10 plants. The data on plant height, number of leaves, diameter and chlorophyll content of leaves were recorded at 90 DAT and yield attributing characters at harvesting of the crop.

The crop was harvested at 130 days after transplanting. The chlorophyll content was measured by adopting standard method.

Bulb per plot was harvested separately and yield per plot was recorded. Yield per ha was obtained by multiplication of factor 5.56 in yield per plot.

\section{Plant growth retardant treatments}

T1Chlormequat 500 ppm

T2Chlormequat 1000 ppm

T3Mepiquat chloride 500 ppm

T4Mepiquat chloride 1000 ppm

T5Brassinolide $0.250 \mathrm{ppm}$

T6Brassinolide $0.500 \mathrm{ppm}$

T7Daminozide 500 ppm

T8Daminozide 1000 ppm

T9Control 


\section{Results and Discussion}

\section{Growth and Physiological attributes}

Table 1 clearly revealed that there were marked variations in growth attributes of plant due to different treatments. The plant height decreased gradually with increasing the concentrations of various growth retardants.

The maximum plant height $(60.28 \mathrm{~cm})$ was recorded at $90^{\text {th }}$ day after transplanting under control followed by plant growth retardants which significantly influenced growth attributes in onion (Table 1). Minimum plant height recorded with Mepiquat chloride 1000 ppm at $90^{\text {th }}$ day after transplanting was 53.50 $\mathrm{cm}$. This might be due to the fact that Mepiquat chloride inhibits Giberellic acid synthesis by stopping the conversion of geranlgeranyldiphosphate to entkaurene, consequently reducing cell enlargement and cell division rate (Srivastava, 2002). Similar findings was also in accordance with Lopex Valencia, 2002 who ascribed that the mechanism of reduction in plant height with Chlormequatamd Mepiquat may be the cause of slowing down of cell division and reduction in cell expansion due to anti-giberellins quality. The maximum number of leaves (10.10) was recorded with $500 \mathrm{ppm}$ of Mepiquat chloride. It was closely followed by Chlormequat 1000 ppm (10.06) whereas, the minimum (8.70) under control. This may be due to the ability of growth retardants to delay senescence of leaf by arresting the chlorophyll degradation and protease activity and promoting. Similar results have also been reported by Memane et al., (2008) for the effect of cycocel on number of leaves in garlic. Similarly, the neck diameter was observed to be maximum $(2.25 \mathrm{~cm})$ under Mepiquat chloride 500 ppm. It was closely followed by chlormequat $1000 \mathrm{ppm}(2.22 \mathrm{~cm})$. It was the minimum (1.82) in control. The thickness of the stem (neck) is the important parameter since it is the neck which is ultimately going to be converted into bulb.

Table.1 Effect of growth retardants for vegetative characters in bellary onion

\begin{tabular}{|c|c|c|c|c|c|}
\hline Treatments & $\begin{array}{c}\text { Plant height } \\
\text { at } 90 \text { days } \\
(\mathrm{cm})\end{array}$ & $\begin{array}{c}\text { No. of } \\
\text { leaves at } 90 \\
\text { days }\end{array}$ & $\begin{array}{c}\text { Neck } \\
\text { diameter } \\
(\mathbf{c m})\end{array}$ & $\begin{array}{l}\text { Root length } \\
(\mathrm{cm})\end{array}$ & $\begin{array}{c}\text { Total } \\
\text { Chl }(\mathrm{mg} / \mathrm{g})\end{array}$ \\
\hline $\mathrm{T}_{1}$ - Chlormequat $500 \mathrm{ppm}$ & 58.57 & 9.86 & 2.10 & 7.50 & 2.13 \\
\hline $\mathrm{T}_{2}$ - Chlormequat 1000 ppm & 56.64 & 10.06 & 2.22 & 8.00 & 2.28 \\
\hline $\mathrm{T}_{3}$ - Mepiquat chloride $500 \mathrm{ppm}$ & 55.10 & 10.10 & 2.25 & 8.15 & 2.49 \\
\hline $\mathrm{T}_{4}$ - Mepiquat chloride $1000 \mathrm{ppm}$ & 53.50 & 9.45 & 1.93 & 7.38 & 1.95 \\
\hline $\mathrm{T}_{5}$ - Brassinolide $0.250 \mathrm{ppm}$ & 56.00 & 9.63 & 2.06 & 7.44 & 2.02 \\
\hline $\mathrm{T}_{6}$ - Brassinolide $0.500 \mathrm{ppm}$ & 54.45 & 9.56 & 1.95 & 7.29 & 1.92 \\
\hline $\mathrm{T}_{7}$ - Daminozide 500 ppm & 60.02 & 10.00 & 2.15 & 7.58 & 2.14 \\
\hline$T_{8^{-}}$Daminozide 1000 ppm & 54.00 & 9.18 & 1.85 & 7.25 & 1.90 \\
\hline $\mathbf{T}_{9-}$ Control & 60.28 & 8.70 & 1.82 & 7.10 & 1.88 \\
\hline SEd & 0.75 & 0.16 & 0.05 & 0.12 & 0.07 \\
\hline $\mathrm{CD}(0.05)$ & 1.49 & 0.31 & 0.09 & 0.22 & 0.13 \\
\hline
\end{tabular}


Table.2 Effect of growth retardants on yield and yield attributing characters in bellary onion

\begin{tabular}{|c|c|c|c|c|c|c|c|c|c|}
\hline Treatments & $\begin{array}{l}\text { Days } \\
\text { taken for } \\
\text { maturity }\end{array}$ & $\begin{array}{c}\text { Diameter } \\
\text { of bulb } \\
\text { (cm) }\end{array}$ & $\begin{array}{l}\text { Height } \\
\text { of bulb } \\
\text { (cm) }\end{array}$ & $\begin{array}{c}\text { Weight } \\
\text { of } \\
\text { bulb(g) }\end{array}$ & $\begin{array}{l}\text { Marketable } \\
\text { yield of bulb } \\
\text { per plot (kg) }\end{array}$ & $\begin{array}{l}\text { Unmarketable } \\
\text { yield of bulb } \\
\text { per plot (kg) }\end{array}$ & $\begin{array}{c}\text { Marketable } \\
\text { yield of bulb } \\
\text { per ha }(q)\end{array}$ & $\begin{array}{c}\text { Unmarketable } \\
\text { yield of bulb } \\
\text { per ha (q) }\end{array}$ & $\begin{array}{c}\text { Total yield } \\
\text { of bulb per } \\
\text { ha }(\mathbf{q})\end{array}$ \\
\hline $\begin{array}{l}\mathbf{T}_{1} \text { - Chlormequat } \\
500 \text { ppm }\end{array}$ & 129.92 & 5.30 & 5.09 & 70.34 & 16.10 & 1.60 & 458.85 & 45.60 & 504.45 \\
\hline $\begin{array}{l}T_{2}-\text { Chlormequat } \\
1000 \text { ppm }\end{array}$ & 129.55 & 5.48 & 5.16 & 72.50 & 16.65 & 1.52 & 474.35 & 43.32 & 517.67 \\
\hline $\begin{array}{l}\mathrm{T}_{3}-\text { Mepiquat } \\
\text { chloride } 500 \text { ppm }\end{array}$ & 127.30 & 5.86 & 5.28 & 76.00 & 17.97 & 1.27 & 512.15 & 36.195 & 548.35 \\
\hline $\begin{array}{l}\mathrm{T}_{4} \text { - Mepiquat } \\
\text { chloride } 1000 \text { ppm }\end{array}$ & 132.66 & 5.10 & 5.00 & 68.42 & 15.32 & 2.15 & 436.62 & 61.28 & 497.90 \\
\hline $\begin{array}{l}\mathrm{T}_{5}-\text { Brassinolide } \\
0.250 \text { ppm }\end{array}$ & 131.33 & 4.86 & 4.95 & 66.00 & 15.25 & 2.30 & 434.63 & 65.55 & 500.18 \\
\hline $\begin{array}{l}T_{6}-\text { Brassinolide } \\
0.500 \text { ppm }\end{array}$ & 133.00 & 4.70 & 4.78 & 61.75 & 14.38 & 2.76 & 409.83 & 78.66 & 488.49 \\
\hline $\begin{array}{l}\mathrm{T}_{7} \text { - Daminozide } 500 \\
\text { ppm }\end{array}$ & 135.00 & 4.55 & 4.69 & 58.66 & 13.88 & 3.00 & 395.58 & 85.50 & 481.08 \\
\hline $\begin{array}{l}T_{8-} \text { Daminozide } 1000 \\
\text { ppm }\end{array}$ & 133.33 & 4.48 & 4.53 & 55.10 & 13.20 & 3.42 & 376.20 & 97.47 & 473.67 \\
\hline $\mathbf{T}_{9-}$ Control & 135.66 & 4.25 & 4.50 & 52.44 & 12.45 & 4.74 & 354.82 & 135.09 & 489.91 \\
\hline SEd & 0.93 & 0.17 & 0.08 & 2.62 & 0.61 & 0.39 & 17.48 & 10.99 & 8.30 \\
\hline $\mathrm{CD}(0.05)$ & 1.85 & 0.33 & 0.17 & 5.18 & 1.21 & 0.78 & 34.44 & 21.65 & 16.43 \\
\hline
\end{tabular}


Hence, more the thickness of the neck more will be the bulb size and yield. These results are in accordance with the findings of Singh $e t$ al., (2003) in Onion. Maximum root length $(8.15 \mathrm{~cm})$ was recorded with Mepiquat chloride $500 \mathrm{ppm}$ which was followed by Chlormequat $1000 \mathrm{ppm}(8.00 \mathrm{~cm})$ and Daminozide $500 \mathrm{ppm}(7.58 \mathrm{~cm})$. Minimum root length $(7.10 \mathrm{~cm})$ was registered in control. These results are in accordance with the findings of Singh and Bhonde(2003) who inferred that soaking of seeds in Cycocel (chlormequat) at $250 \mathrm{ppm}$ of onion cultivars Agrifound Light Red increased the root length and 100 seedling weight as compared with control. Significant difference exhibited among various treatments for Total chlorophyll of leaves. Growth retardants had profound influence on chlorophyll content in leaf. The maximum total chlorophyll (2.49 $\mathrm{mg} / \mathrm{g}$ ) was recorded with Mepiquat chloride $500 \mathrm{ppm}$ followed by Chlormequat $1000 \mathrm{ppm}$ $(2.28 \mathrm{mg} / \mathrm{g})$. Minimum was registered under control (1.88).Nevertheless, Daminozide 500 ppm $(2.14 \mathrm{mg} / \mathrm{g})$ was at par with Chlormequat $500 \mathrm{ppm}(2.13 \mathrm{mg} / \mathrm{g})$. It would be possible that the chlorophyll synthesis is enhanced due to some mild stress created by growth inhibitors and retardants and also the chlorophyllase enzyme, responsible for chlorophyll degradation. The results are in conformity with the findings of Sunil kumar pal et al., (2017). Cheema et al., (2009) found that application of growth retardants at 35 days after sowing in cowpea increased the total chlorophyll content.

\section{Yield attributes and yield}

Significant effects of various treatments were observed on yield parameter (Table 2). Early days to maturity of bulb was recorded with mepiquat chloride 500 ppm (127.30). Nevertheless, Chlormequat $1000 \mathrm{ppm}$ and Chlormequat 500 ppm recorded on par with each other (129.55 and 129.92,
respectively).Maximum days taken for maturity were recorded with control (135.66). Bulb size is an important yield contributing character in onion. Regarding bulb diameter, the highest diameter of bulb $(5.86 \mathrm{~cm})$ was recorded with mepiquat chloride $500 \mathrm{ppm}$. It was closely followed by chlormequat 1000 ppm $(5.48 \mathrm{~cm})$ whereas the lowest $(4.25 \mathrm{~cm})$ diameter of bulb was recorded under control which remains at par with Daminozide 1000 ppm $(4.28 \mathrm{~cm})$. The greatest $(5.28 \mathrm{~cm})$ height of bulb was observed with mepiquat chloride 500 ppm followed by treatment of chlormequat $1000 \mathrm{ppm}(5.16 \mathrm{~cm})$. The lowest $(4.50 \mathrm{~cm})$ height of bulb was recorded under control. Highest bulb weight (76.00 g) was registered in mepiquat chloride 500 ppm which was closely followed by Chlormequat 1000 ppm (72.50 g) and Chlormequat 500 ppm (70.34 g). Lowest bulb weight (52.44 g) was recorded with control. Significant effects of various treatments were observed on yield parameter. The reduction in plant height by growth regulators and chemicals was effective in moderating the vegetative growth by mobilizing the photosynthates from other parts to the bulbs and activating synthetic enzymes thereby increasing the bulb size. The results are in conformity with the findings of Singh et al., (2003). The bulb yield had significant positive association with number of leaves, bulb length and chlorophyll content indicating the importance of these parameters in improving the yield potential of onion. The maximum marketable yield per plot and yield per ha (17.97 kg and 512.15q, respectively) was observed with mepiquat chloride 500 ppm. The minimum marketable yield per plot and yield per ha $(12.45 \mathrm{~kg}$ and $354.82 \mathrm{q}$ respectively) was recorded in control. The minimum unmarketable yield per plot and yield per ha $(1.27 \mathrm{~kg}$ and $36.195 \mathrm{q}$, respectively) was observed with mepiquat chloride 500 ppm. The maximum unmarketable yield per plot and yield per ha (4.74 $\mathrm{kg}$ and $135.09 \mathrm{q}$ respectively) was 
recorded in control. Highest total yield of bulb per ha 548.35 q was registered in mepiquat chloride $500 \mathrm{ppm}$ and the minimum with control (481.08 q). The production of large sized bulbs with the growth retardant may be attributed to the fact that growth retardants remain physiologically more active to build up sufficient food reserves for developing bulbs which ultimately lead to increased total yields (Memane et al., 2008). Similar findings regarding the yield have also been reported by Reddy (2009) and Kumar et al., (2010).

\section{References}

Bhonde S R, Mish V K and Chougule A B. 1996. Effects of frequency of irrigation and nitrogen level on yield and quality of onion seed variety Agrifound Light Red. Newslet. Nat. Hort.

Cheema, M.S., Akhtar, M. and Nasarullah, M.(2009) Effect of foliar application of mepiquat chloride under varying nitrogen levels on seed cotton yield and yield components. Journal of Agricultural Research 47(4): 381.

Kumar, V., Vyakarnahal, B. S., Basavaraj, N. and Birbal (2010) Effect of growth retardants and methods of application on growth and yield of potato. Indian Journal of Horticulture, 67: 308-313.

Lopez Valencia, M., Sanchezdel Castillo, F. and Contreras Magana, E. (2002) Effect of cycocel and B9 on tomato (Lycopersicon esculentum Mill.) plants pruned to two clusters. Revista Chapingo Serie Horticultura, 8(2): 161170.

Memane, P. G., Tomar, R. S., Kakade, D. K.,
Kulkarni, G. U. and Chovatia, R. S. (2008). Effect of clove weight and plant growth regulators on growth and yield of garlic (Allium sativum L.). Asian Journal of Horticulture 3(1): 82-86.

Pandey, M. (2017) Effect of FYM and manganese on yield and uptake of nutrients by onion (Allium cepa) in an alluvial soil. Annals of Plant and Soil Research 19 (2): 180-184.

Reddy, P., Ninganur, B. T., Chetti, M. B. and Hiremath, S. M. (2009) Effect of growth retardants and nipping on chlorophyll content, nitrate reductase activity, seed protein content and yield in cowpea (Vigna unguiculata L.). Karnataka Journal of Agricultural Sciences, 22(2): 289-292.

Res., Dev. Found 16(3): 4-7.

Singh, D. K. and Bhonde, S. R. (2003) Studies on the efficacy of certain growth regulators on seed viability and vigour in onion. National Horticultural Research and Development Foundation 23(1): 10-16.

Singh, D. K., Singh, N. B. and Bhonde, S. R. (2003) Effect of growth regulators on bulb development in onion during kharif season. National Horticultural Research and Development Foundation 23(2): 14.

Srivastava, L. M. (2002) Gibberellins. In: Srivastava, L. M. Plant growth and development Academic Press, New York, USA. pp. 172-181.

Sunil Kumar Pal et al., (2017). Effect of mepiquat chloride on growth and yield of onion (Allium cepa). Annals of Plant and Soil Research 19(4): 377-380.

\section{How to cite this article:}

Manivannan, M. I., J. Prem Joshua and Arulmozhiyan, R. 2021. Studies on Influence of Growth Retardants in Increasing Yield and Yield Attributing Traits in Bellary Onion (Alium cepa var.Cepa). Int.J.Curr.Microbiol.App.Sci. 10(08): 134-139.

doi: https://doi.org/10.20546/ijcmas.2021.1008.017 